\title{
D. M. DE VRIES' evolution to plant sociologist
}

\section{A. SCHEYGROND}

State Secondary School and Municipal Grammar School, Gouda, Netherlands

Dinand Marius De VRIEs was born at Gouderak on 15th April, 1900, in the centre of the flat polderland in the province of South Holland, where the scenery is dominated by grassland, ditches and canals. His rural surroundings and the excellent tuition he received in natural history from Dr. JоH. H. vaN BURKOM at the Gouda State Grammar School were reasons that decided him to study biology, especially zoology, at the State University of Utrecht. During his study at the University he was especially interested in insects and free-living nematodes. Only in the last few years his attention was greatly drawn to the remarkable differences that may occur in the botanical composition of grassland vegetations. The subject he selected for study under Dr. A. A. Pulle, professor in specialized botany, was decisive for his development as a biologist. Professor PULLE allowed DE VRIES to study the flora of his own countryside, the "Krimpenerwaard".

During an excursion Prof. Pulle drew his attention to plant sociology, a recently developed branch of science. DE VRIES was so much interested that he studied the vegetation of this area on the basis of this new concept. By the end of the summer of 1924 he succeeded in producing the first phytosociological data. These concerned the poor hayfields (also known as "blue grasslands") in the "Krimpenerwaard". The material DE VRIES collected from this area led to the publication "Het plantendek van de Krimpenerwaard I" (The plant cover of the Krimpenerwaard I), published in the Nederlandsch Kruidkundig Archief of 1925 . It was the first phytosociological publication with data on a Dutch vegetation. This preliminary paper showed that DE VRIES had opinions of his own which closely corresponded to those of representatives of the "Northern School".

When DE VRIES started his investigations in the "Krimpenerwaard" only some 80 ha of poor hayfields were left. At the moment, the poor hayfield of 2.5 ha near the decoy "Kooilust" at Berkenwoude is the only one that remains. Fortunately, DE VRIES managed in good time to sample all poor hayfields known to him.

1926 was mainly devoted to informative research. In the meantime DE VRIEs had enlisted the co-operation of two younger fellow students from Gouda, M. J. J. PEETers (who died in 1928) and A. Scheygrond, both pupils of Prof. Pulle. With his infectious enthusiasm he had succeeded in interesting them in this new science. These three - soon to be capably assisted by A. C. BoER of Gouderak - made many excursions in the "waard", firstly, in order to widen his phytosociological knowledge, and secondly to find a basis for a more detailed investigation of the plant cover. Botany was included; plants were collected and identified. The result of this botanical research was reflected in a second article on the plant cover of the "Krimpenerwaard" in the Nederlandsch Kruidkundig Archief of 1927.

Based on the informative research undertaken in the summer of 1926, a plan was designed for the sociological research in the winter of 1926-1927 of all the original plant cover. 1927 was the most active year. DE VRIES sampled the vegetation of the

Received for publication 12th January, 1965. 
remaining poor hayfields (he called this the chief association complex Molinietum coeruleae-Agrostidetum caninae). At the same time the hayfields of the peat embankments and the "Lekkerkerkse boezem" (reservoir) (the chief association complex Agrostidetum caninae-Holcetum lanati) were analysed, the same method being employed as in sampling the poor hayfields. In the same summer the disused and siltedup polder reservoirs near Gouderak were sampled (the chief association complex Arundinetum-Sphagnetum).

DE VRIEs' share of the work resulted in a thesis entitled "Het plantendek van de Krimpenerwaard. III" (The plant cover of the Krimpenerwaard. III), with which he obtained his Doctor's degree, with honours, at the University of Utrecht on 4th July, 1929. Professor Pulle was, of course, his promotor. He had remained deeply interested in and had greatly stimulated research on the plant cover of the "Krimpenerwaard". Peeters wrote another article on the hay embankments and the "Lekkerkerkse boezem" (reservoir), but owing to his premature death his work was not completed.

Scheygrond obtained his Doctor's degree from Professor Pulle in 1931 with a thesis on the plant cover of the "Gouderakse boezems" (reservoirs). This was part IV of the publications in the Nederlandsch Kruidkundig Archief. BoER was not yet ready for publishing at this time, being an entirely self-taught man. He and SchEYGROND, however, may consider themselves as DE VRIES' first pupils. He informed them about the problems and methods of phytosociological research in the field, and there were many discussions at his apartment in his parental home. He was in the best sense of the word their scientific guide.

DE VRIEs' interest in nature and biology was by no means one-sided. During his secondary school education he bred and collected butterflies and succeeded in catching some rare species in the "Krimpenerwaard". Under professor H. J. JoRDAN he carried out research on the digestion of Notonecta glauca with reference to comparative animal physiology and was able to prove the existence of external digestion. This work was so thorough and detailed that he could certainly have written a thesis with the material, had he not been fascinated by plant sociology.

Moreover, during his study DE VRIES was a member of the "Gouda Ornithological Society" though not a very active one at the time. Little did he dream at this period what a great source of pleasure this hobby would grow into and the scientific prospects it was to afford him. The agricultural economist C. P. G. J. SMIT was the chairman of this bird-watching society. SMIT had intended to make a geological study of the peat in the "Krimpenerwaard", but never carried it out. He was, however, deeply interested in the work of DE VRIES and his two fellow members. His many discussions with DE VRIES about the problems confronting the latter and his co-workers were of much importance to the solution of their difficulties.

After he had done some teaching at the Gouda State Grammar School from 11th March to 20th April, 1929, to replace his former teacher for some time, DE VRIES left his beloved "Crempene". On 7th August, 1929, he was appointed botanist at the Groningen Agricultural Experiment Station, where his main subject was grassland research. The work in the "Krimpenerwaard" was terminated at the same time. His aim of describing all original plant associations in this area was never realised. After the SCHEYGRoND thesis, a summarizing survey was published in the booklet "Botanische Landschapstudies" (Botanical Landscape Studies) (Groningen) in 1934, which also included the most important results of PeEters' work. But the first part of DE VRIEs's scientific career ended in 1929. 